\title{
THE INFLUENCE OF ORGANIZATION CAPABILITIES AND ENTREPRENEURSHIP TO COMPETITIVE ADVANTAGE IN GOODNESS OF TASTE AND THE IMPLICATION TO BUSINESS PERFORMANCE IN SME RESTAURANTS, SEMARANG
}

\author{
Artsswinda Ayu Bungara \\ Master of Management, Faculty of Economics and Business, Diponegoro University
}

\begin{abstract}
This research was aimed to analyze the influence of capabilities organization and entrepreneurship to increase business performance that can be moderated by competitive advantage, which is focused on goodness of taste, for restaurants in Semarang. Based on pre survey in 20 owners of restaurant, it can be concluded that there was decreasing income about $22 \%(\mathrm{Rp} 335.000,00)$ and was followed by decreasing of market share about 0,56\% during 3 months. It was interesting because the restaurants are one of SME that many people interested in it. In other hand, many people work in this sector as their main job.

The samples of this research are the restaurants that include in SME, which employ 5 19 employees. This research used 150 respondents, but only 124 respondents who fulfill the requirement. The data were collected by using questionnaires and direct interviews to the owners of restaurants in Semarang. This research proves 5 (five) hypothesis that were built by capabilities organization, entrepreneurship, competitive advantage in goodness of taste, and business performance. The results was analyzed by AMOS.

It can be concluded that the model is feasible. The results of this study indicate that the business performance can be increased directly by a good management of capabilities organization and indirectly can be reached by focusing to maintain the resources. It because the restaurants that include as SME have a limit resource.
\end{abstract}

Key Words: Capabilities Organization, Entrepreneurship, Competitive Advantage in Goodness of Taste, Business Performance.

\section{INTRODUCTION}

Business performance of SME restaurants in Semarang showed declining. Almost $75 \%$ owners of SME restaurant felt it (survey, 2016). This phenomena can be seen from the decline of average income per days about Rp $355.000,00$ in 3 (three) months. It was because of the increase of SME restaurants.
It give an impact in decreasing market share for small scale (almost 0,56\%). This condition become a centre of point because this sectors have some limitations (Bakar dan Ahmad, 2010; Herman, 2012; Ndubisi dan Iftikhar, 2012). This limitation make owners should find some strategy to increase business performance and could win or at least survive in competition.

${ }^{1}$ Corresponding author, Email: artsswinda.ayu@gmail.com 


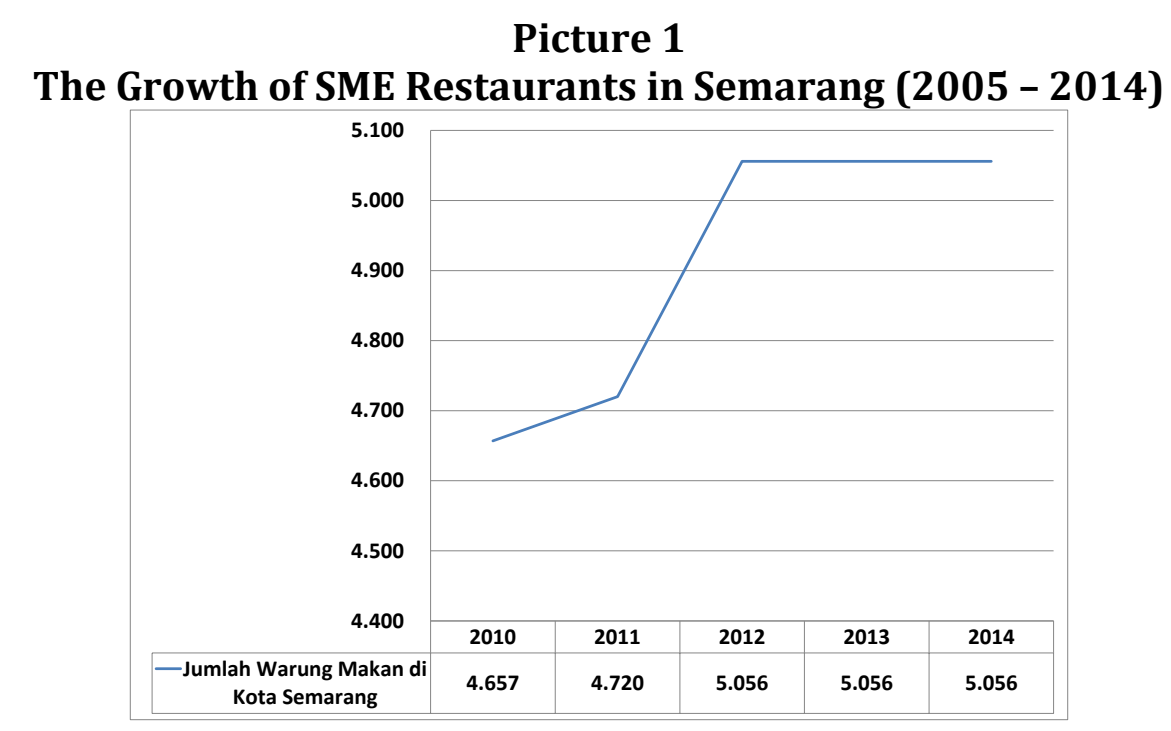

Source: BPS (2005 - 2014)

Monsur dan Yoshi (2011) stated that if the owners want to have a good performance should have ability to compete. Competitive advantage is the conditions when business become superior to win the competition. The main attraction of SME restaurants is the goodness of taste that can interest the buyers. The taste become important because could influence buying decision and could impact to business perfomance wholly.

Pérez-de-Lema, Alfaro-Cortes et al. (2012) said that competitive advantage could be got by The good organization capabilities. Liu, Hou et al. (2011) define the organization capabilities as ability to interact wheter socially or economically. The good capabilities can be formed by the good competences. Human resources who has competeces become a critical factor to reach the success (Todericiu, Serban et al, 2013; Kurniawati dan Yuliando, 2014). It because the quality of human resources is something unique and hard to immitate or to has like other resources. In contrary, Price dan Stoica (2015) said that human resources and social aspects doesn't important to create a good performance.

Lee dan Chu (2011); Liu, Hou et al. (2011); Kurniawati dan Yuliando (2014) said that not only organization capabilities but also entreprenuership could form competitive advantage to make a good performance. Entreprenuership can be defined as an ability to continously create, see, and take the opportunities. (Ndubisi dan Iftikhar, 2012). The SME restaurants which is superior than the other will have an opportunity to win the competition. It because The SME restaurants have a better performance than another competitors, thus it will be more flexible to face the dynamic of business. Awang, Khalid et al. (2009); Arshad, Rasli et al. (2013); Lee, Hallak et al. (2015) didn't agree with that statement and said that entreprenuership doesn't have impact to business performance.

Based on the explanations before, some questions which were tested in this research are:

1. Does the competitive advantage in goodness of taste has possitive impact to business performance?

2. Does the organization capabilities has possitive impact to business performance?

3. Does entreprenuership has possitive impact to business performance? 
4. Does the organization capabilities has possitive impact to competitive advantage in goodness of taste?

5. Does entreprenuership has possitive impact to competitive advantage in goodness og taste?

\section{LITERATURE REVIEW Organization Capabilities}

Liu, Hou et al. (2011) said that the organization capabilities include an ability to stay connect wheter in economically or socially. Tibon (2015) stated that the relationship which is made from trust even within organization or between stakeholder is a main factor to face the dynamic of business. Relationship between stakeholder include a good relationship with suppliers and buyers. Buyer relationship could be formed with marketing strategy, coordination, and a good service (Limakrisna, Sudarso et al, 2015).

The output of SME restaurant's activites are foods and services. The quality of foods and services could be reached if the owner has a good organization capability (Joung, Goh et al, 2015). The organization capabilities can be formed by individual capabilities that become united to create foods and services (Arik dan Dunne, 2014).

Ghazali, Nasyira et al. (2014) agree with that statement and said that a good organization capability could impact willingness to work for the employees. Todericiu, Serban et al. (2013) told that employees who have a high work motivation are main factor to effectively and sustainability make a success organization.

\section{Entreprenuership}

Entreprenuership is a factor which impact to business performance (Zhang dan Zhang 2012; Limakrisna, Sudarso et al, 2015; Price dan Stoica, 2015). Limakrisna, Sudarso et al. (2015) said that one of entreprenuership dimensions is innovation. Innovation means not only create something new, but also modificate the product which could increase the appresiation of buyers (Tüzünkan dan Albayrak, 2015).

Other dimensions of entreprenuership is proactive (Miller dalam Awang, Khalid et al, 2009) dan kemandirian (Lumpkin dan Dess in Awang, Khalid et al.,2009). Proactive can be defined as the ability to actively search business opportunities which is profitable. Almeida, Bremser et al. (2014) stated that proactive has positive relationship to organization capabilities to face the dynamic of business. Arshad, Rasli et al. (2013) agree with that statement and said that independence could build confidence to create something creative.

\section{Competitive Advantage in Goodness of Taste}

Mahdi, Almsafir et al. (2011) said that competitive advantage can be intepreted as a superior possition in a long term with a sustainable improvisation. The quality of foods become the most important thing to restaurant to buid competitive advantage (Ryu, Lee et al, 2010; Majid, Alias et al, 2016). It because the quality of foods could impact the reputation of restaurants and buyer perceptions which is customer satisfaction and willingness of repurchase or giving recomendastion to the other. Munjal dan Sharma (2012) added the statement that the owners should manage the materials with a proper way, thus cost become more efficient and continiously improve the quality of foods to increase the buyer trust.

\section{Business Performance}

The output of restaurant's activites are foods and services that is served for buyers (Min dan Min, 2011). Tomescu dan Botezat (2014) agree with that statement and said that most people come to restaurant to try, smell, and find various foods. The 
employee of restuarant should participate to increase business performance to create quality as well as buyer expectations. Total sales become a tool to measure business performance (Limakrisna, Sudarso et al, 2015). Lee, Hallak et al. (2015); Limakrisna, Sudarso et al. (2015) said that business performance can be measured by calculate the growth of buyers, sales, assets, and capitals. All within organization should imply strategies to create competitive advantage and achieve the targets (Pérez-de-Lema, Alfaro-Cortes et al, 2012).

Based on preliminary and literature review, some hypothesis that were tested in this research are:

$\mathrm{H} 1$ : "Competitive of advantage in goodness of taste has positive impact to business performance"

H2: "Organization capabilities has positive impact to business performance"

H3: "Entreprenuership has positive impact to business performance"

H4: "Organization capabilities has positive impact to competitive of advantage in goodness"

H5: "Entreprenuership has positive impact to competitive of advantage in goodness"

\section{METHOD}

Population of this research is all of SME restaurants in Semarang. The SME restaurants were defined as business which focused on foods and have a permanent place (even partially or wholly) and not moving, but still doesn't have a legal permission from government (Airlangga, Suharni et al, 2015). Other requirement that needed to fullfill is SME restaurants should employ $5-19$ employee like BPS stated to identify small sector. The number of respondents of this research is 150 respondents with random sampling method. This research used Structural Equation Model (SEM) with AMOS to analyze the result.

AMOS calculate the output estimation based on data in questionnaires that already gave to the respondents. Questionnaires are distributed by coming one by one to the owners of SME retaurants in Semarang. Indicators is formed based on litterature review and explained become questions of questionnaires for respondents. Here some indicators which is used in this research:

Table 1

Conceptual Definition and Indicators of Research

\begin{tabular}{|c|c|c|c|c|c|}
\hline $\begin{array}{l}\mathbf{N} \\
\mathbf{o}\end{array}$ & Variable & $\begin{array}{l}\text { Conceptual } \\
\text { Definition }\end{array}$ & Indicator & $\begin{array}{c}\text { Symb } \\
\text { ol }\end{array}$ & $\begin{array}{c}\text { No } \\
\text { Questio } \\
\text { nnaire }\end{array}$ \\
\hline \multirow{4}{*}{1} & $\begin{array}{l}\text { Organization } \\
\text { capabilities (X.1) }\end{array}$ & \multirow{4}{*}{$\begin{array}{l}\text { Orgaization } \\
\text { capabilities can } \\
\text { be defined as } \\
\text { ability to stay } \\
\text { connect wheter } \\
\text { econonically or } \\
\text { socially (Liu, } \\
\text { dkk, 2015) } \\
\end{array}$} & $\begin{array}{l}\text { Ability to increase spirit for } \\
\text { employee }\end{array}$ & X.1.1 & $\mathrm{P} 1$ \\
\hline & \multirow{3}{*}{$\begin{array}{l}\text { (Mutahar, 2015; } \\
\text { Limakrisna, } \\
\text { 2015; Pérez-de- } \\
\text { Lema, Alfaro- } \\
\text { Cortes et al. } \\
(2012) \text { ) }\end{array}$} & & Employee dicipline & X.1.2 & P2 \\
\hline & & & Ability to connect to the buyers & X.1.3 & P3 \\
\hline & & & $\begin{array}{l}\text { Ability to connect to the } \\
\text { suppliers }\end{array}$ & X.1.4 & P4 \\
\hline 2 & $\begin{array}{l}\text { Entreprenuershi } \\
\mathrm{p}(\mathrm{X} .2)\end{array}$ & $\begin{array}{l}\text { Entreprenuershi } \\
\text { p can be defined } \\
\text { as ability to }\end{array}$ & $\begin{array}{l}\text { Find a new way to create food } \\
\text { to attract the buyers } \\
\text { (innovation) }\end{array}$ & X.2.5 & P5 \\
\hline
\end{tabular}




\begin{tabular}{|c|c|c|c|c|c|}
\hline & \multirow{2}{*}{$\begin{array}{l}\text { (Limakrisna, } \\
\text { 2015; Lee, dkk, } \\
\text { 2015; Liu, dkk, } \\
\text { 2011) }\end{array}$} & \multirow{2}{*}{$\begin{array}{l}\text { continiously } \\
\text { create, see, and } \\
\text { gather } \\
\text { opportunities } \\
\text { (Ndubisi dan } \\
\text { Iftikhar, 2012) } \\
\end{array}$} & $\begin{array}{l}\text { Ability to get business } \\
\text { opportunity (Proactive) }\end{array}$ & X.2.6 & P6 \\
\hline & & & $\begin{array}{l}\text { Ability to face dynamic of } \\
\text { business (Independence) }\end{array}$ & X.2.7 & P7 \\
\hline \multirow{4}{*}{3} & $\begin{array}{l}\text { Business } \\
\text { Performance } \\
\text { (Y.1) }\end{array}$ & \multirow{4}{*}{$\begin{array}{l}\text { The success of } \\
\text { organization } \\
\text { because internal } \\
\text { process that } \\
\text { already did in a } \\
\text { certain periode }\end{array}$} & The growth of sales & Y.1.1 & P8 \\
\hline & \multirow{3}{*}{$\begin{array}{l}\text { (Limakrisna, } \\
\text { 2015; Lee, dkk, } \\
\text { 2015) }\end{array}$} & & The growth of buyers & Y.1.2 & P9 \\
\hline & & & The growth of assets & Y.1.3 & $\mathrm{P} 10$ \\
\hline & & & The growth of capital & Y.1.4 & P11 \\
\hline \multirow{4}{*}{4} & $\begin{array}{l}\text { Competitive } \\
\text { advantage in } \\
\text { goodness of } \\
\text { taste }\end{array}$ & \multirow{4}{*}{$\begin{array}{l}\text { Can be defined } \\
\text { as a condition } \\
\text { which has a } \\
\text { strong taste to } \\
\text { win the } \\
\text { competitions }\end{array}$} & $\begin{array}{l}\text { Ability to cook a new food } \\
\text { which which is still rare in the } \\
\text { market }\end{array}$ & Y.2.5 & $\mathrm{P} 12$ \\
\hline & \multirow{3}{*}{$\begin{array}{l}\text { (Lee, 2015; } \\
\text { Mutahar, dkk, } \\
\text { 2015; Wood, } \\
\text { 2014; Monsur } \\
\text { dan Yoshi, 2011) }\end{array}$} & & $\begin{array}{l}\text { Ability to cook with hygiene } \\
\text { standards }\end{array}$ & Y.2.6 & P13 \\
\hline & & & $\begin{array}{l}\text { Ability to combine materials } \\
\text { become a perfect combination }\end{array}$ & Y.2.7 & $\mathrm{P} 14$ \\
\hline & & & Abiliry to cook with no MSG & Y.2.8 & P15 \\
\hline
\end{tabular}

Source: Literature review (2016)

\section{RESULT AND DISUCUSSION Normality Test}

Based on normality test, there is 3 (three) indicators which have $\mathrm{CR}$ value greater than $\pm 2,58$, but C.R value for multivariate is still in that range $(-1,379)$. This result showed that the model already distributed normally. Three indicators which have CR value more than $\pm 2,58$ are X.1.2, X.1.3, dan X.1.4.

\section{Outlier Evaluation}

Mahalnobis distance can be seen at ChiSquare table. Mahalnobis distance for $\chi$ (15; 0,001$)$ adalah 30,578 . The output of this research is about $10,845-28,787$. It showed that no data has an extreme value.

\section{Realibility Test}

Reability test can be known by calculate value of Composite Realibility (CR). A good CR can be defined if the output greater than 0,7 . The output can be seen at table 2 .

Table 2

CR Value

\begin{tabular}{lrrrrr}
\hline \multicolumn{1}{c}{ Variable } & $\begin{array}{c}\text { Sum of } \\
\text { Loading } \\
\text { Standard }\end{array}$ & $\begin{array}{c}\text { Squared of Sum } \\
\text { Loading } \\
\text { Standard }\end{array}$ & $\begin{array}{c}\text { Sum of } \\
\text { Error } \\
\text { Standard }\end{array}$ & $\begin{array}{c}\text { Squared of } \\
\text { Sum Error } \\
\text { Standar }\end{array}$ & C.R \\
\hline Organization_Capabilities & 3,46 & 11,9716 & 0,54 & 0,2916 & 0,976222 \\
\hline Entreprenuership & 2,534 & 6,421156 & 0,466 & 0,217156 & 0,967287 \\
\hline Competitive_Advantage & 3,401 & 11,5668 & 0,599 & 0,358801 & 0,969913 \\
\hline Business_Performance & 3,367 & 11,33669 & 0,633 & 0,400689 & 0,965862 \\
\hline
\end{tabular}

Source: Data (2017)

Table 4.3 showed that four variables in this research has value of CR greater than 0,7 (about 0,965962 - 0,976222). It indicate that all of variables reliable to measure.

\section{Validity Test}

Validity test can be known from Average Variance Extraced (AVE). If value AVE greater than 0,5 , it can be conclude that 
the variables have a good validity. Output

AVE can be seen at table 3 .

Table 3

Value of AVE

\begin{tabular}{lrrc}
\hline \multicolumn{1}{c}{ Variable } & Jumlah Kuadrat Standar Loading & JumlahStandar Eror & AVE \\
\hline Organization_Capabilities & 2,999682 & 1,000318 & 0,749921 \\
\hline Entreprenuership & 2,144134 & 0,855866 & 0,714711 \\
\hline Competitive_Advantage & 2,894475 & 1,105525 & 0,723619 \\
\hline Business_Performance & 2,838197 & 1,161803 & 0,709549 \\
\hline
\end{tabular}

Source: Data (2017)

Table 03 showed that 4 (four) variables in this research has value AVE greater that 0,5 (about 0,709549 - 0,749921).It means all of variables valid to measure.

\section{Discriminant Validity Test}

Discriminant validity test can be calculated by root of Average Variance Extraced

\section{Table 4}

Correlation Between Latent Variable and Root of AVE

\begin{tabular}{lrrrr}
\hline & $\begin{array}{c}\text { Organizatio } \\
\text { n_Capabilities }\end{array}$ & $\begin{array}{c}\text { Entreprenu } \\
\text { ership }\end{array}$ & $\begin{array}{c}\text { Competitive_Ad } \\
\text { vantage }\end{array}$ & $\begin{array}{c}\text { Business_ } \\
\text { erformance }\end{array}$ \\
\hline Organization_Capabilities & $\mathbf{0 , 8 6 5 9 8}$ & & & \\
\hline Entreprenuership & 0,188 & $\mathbf{0 , 8 4 5 4 0 6}$ & & \\
\hline Competitive_Advantage & 0,502 & 0,385 & $\mathbf{0 , 8 5 0 6 5 8}$ & \\
\hline Business_erformance & $-0,101$ & $-0,538$ & $-0,638$ & $\mathbf{0 , 8 4 2 3 4 7}$ \\
\hline
\end{tabular}

Source: Data (2017)

Table 04 showed that roots of AVE have value between 0,842347 - 0,86598. It indicate a good result because value correlation of latent variable less than root of AVE.

\section{Confirmatory Factor Analysis Test (Full Model)}

(AVE). It show a good result if value root of AVE greater than value correlation of latent variable. Correlation between latent variable and root of AVE can be seen at table 4.
Full model in this research can be seen at picture 2. Picture 2 is made from exogen variables and endogen variables which is connected by single arrow. Result based on goodness - of - Fit criteria can be seen at table 5 .

Table 5

Output of Goodness - of - Fit Full Model Criteria

\begin{tabular}{cccc}
\hline Criteria & Standard & Estimation & Note \\
\hline CMIN & Chi - square Value & 83,591 & Confirm \\
\hline CMIN/DF & $<2$ & 0,995 & Confirm \\
\hline GFI & $0-1$ & 0,916 & Confirm \\
\hline RMSEA & $<0,08$ & 0,000 & Confirm \\
\hline AGFI & $\geq 0,90$ & 0,880 & Moderate \\
\hline TLI & $0-1$ & 1,000 & Confirm \\
\hline NFI & $0-1$ & 0,942 & Confirm \\
\hline PGFI & $0-1$ & 0,641 & Confirm \\
\hline
\end{tabular}

Source: Data (2017) 
Table 5 showed that there is one of eight variables has moderate criteria because didn't fulfill the requirement. This condition can be tolerated, the model still fit to analyze.

Picture 2

Hasil Estimasi Full Model

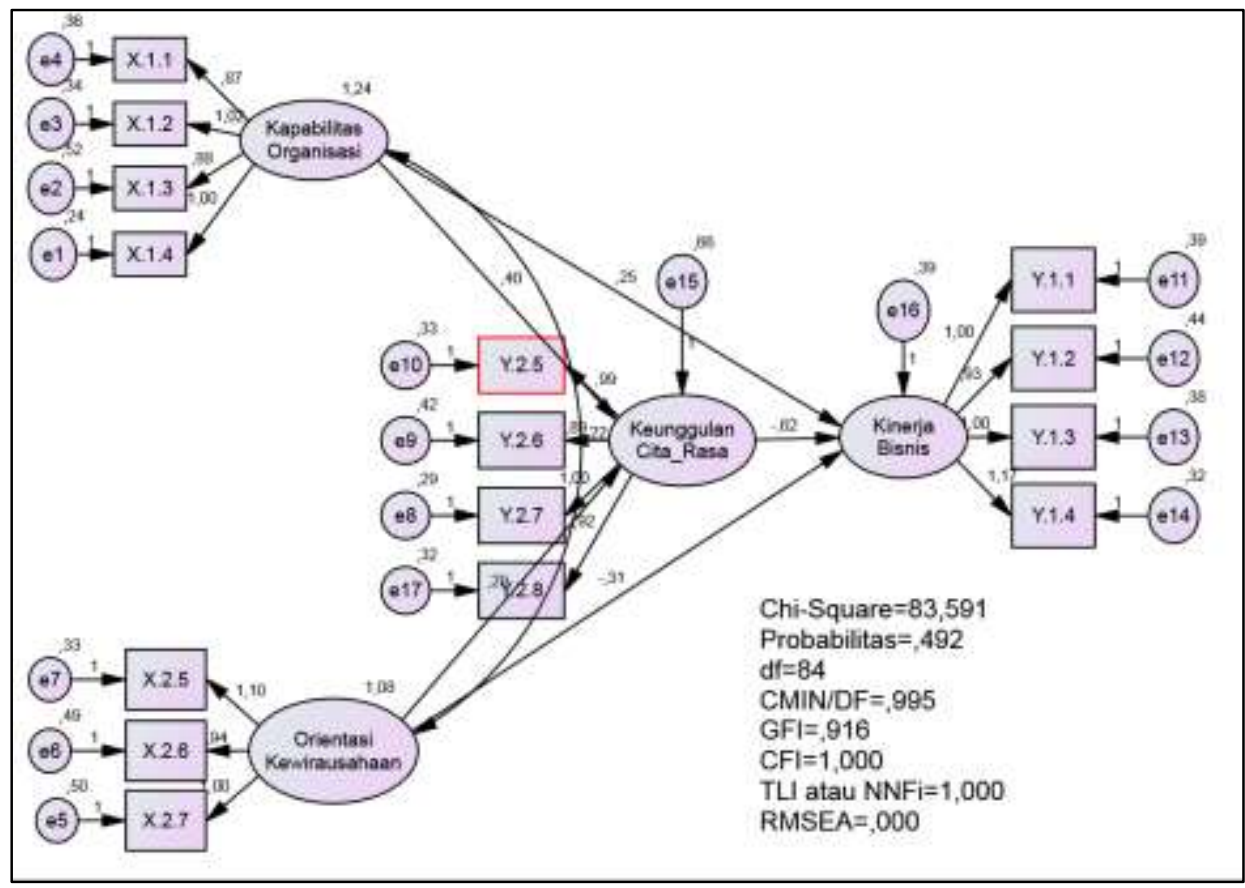

Sumber: Processed data (2017)

\section{The Dirrect and Indirect Impact}

This research aimed to analyze the impact of organization capabilities and entreprenuership to business performance. This relationship also be moderated by competitive advantage in goodness of taste, so there is direct and indirect impacts. Calculation of direct and indirect impact can be seen at table 6 .

Table 06 showed that direct impact which is formed by organization capabilities and business performance is 0,29 dan indirect impact of that is $-0,2897$.
Total impact of organization capabilities and entreprenuership is 0,000305 . Lack of impact is caused by a significantly negative relationship between competitive advantage im goodmess of taste and business performance.

The direct impact between entreprenuership and business performance is $-0,342$. The indirect impact between entreprenuership and business performance is $-0,10328$, so total impact ofthat is $-0,44528$.

Table 6

Direct and Indirect Impact

\begin{tabular}{l|l|r}
\hline \multicolumn{1}{c|}{ Relationship } & \multicolumn{2}{c}{ Impact } \\
\hline Organization Capabilities - Business Performance & & \\
\hline Direct Impact: & & 0,29 \\
Organization Capabilities - Business Performance & $(0,445)$ & \\
\hline $\begin{array}{l}\text { Indirect Impact: } \\
\text { Organization Capabilities - Competitive Advantage in Goodness of Taste } \\
\text { Competitive Advantage in Goodness of Taste - Business Performance }\end{array}$ & $(-0,651)$ & $-0,2897$ \\
\hline
\end{tabular}




\begin{tabular}{l|l|r}
\hline \multicolumn{1}{c|}{ Total } & $\mathbf{0 , 0 0 0 3 0 5}$ \\
\hline Entreprenuership - Business Performance & & \\
\hline Direct Impact: & & $-0,342$ \\
Entreprenuership - Business Performance & $(0,302)$ & \\
\hline $\begin{array}{l}\text { Indirect Impact: } \\
\text { Entrepenuership - Competitive Advantage in Goodness of Taste } \\
\text { Competitive Advantage in Goodness of Taste - Business Prformance }\end{array}$ & $(-0,342)$ & $-0,10328$ \\
\hline \multicolumn{1}{c|}{ Total } & $\mathbf{- 0 , 4 4 5 2 8}$ \\
\hline
\end{tabular}

Source: Data (2017)

\section{Hypothesis Test}

Based on ouput estimations, the result of hypothesis test can be seen in table 7 .

Tabel 7

Rangkungan Hasil Uji Hipotesis

\begin{tabular}{|c|c|c|c|c|}
\hline No & Hypothesis & Result & Interpretation & Conclusion \\
\hline 1 & $\begin{array}{l}\text { H1 : } \\
\text { "Competitive } \\
\text { advantage in } \\
\text { goodness of taste has } \\
\text { positive impact to } \\
\text { business } \\
\text { performance" }\end{array}$ & $\begin{array}{l}\text { CR : -6,268 } \\
P<0,05 \\
\text { Output } \\
\text { estimation: } \\
-0,620\end{array}$ & $\begin{array}{l}\text { Competitive advantage in goodness og } \\
\text { taste has negative impact to business } \\
\text { performace. The impact of that is } 62 \% \text {, } \\
\text { so ther is } 38 \% \text { consist of other factors } \\
\text { which has impact to business } \\
\text { performance. }\end{array}$ & $\begin{array}{l}\text { Accepted with } \\
\text { significantly } \\
\text { negative } \\
\text { relationship }\end{array}$ \\
\hline
\end{tabular}

Discussion H1: this result is in line with Setyawati (2012) who said competitive advantage don't have influence to business performance. It is caused by measuremet of business performance has subjective indicators and based on assumption. It probably a different measurement and make the result not always has positive impact.

\begin{tabular}{|c|c|c|c|c|}
\hline No & Hypothesis & Result & Interpretation & Conclusion \\
\hline 2 & $\begin{array}{l}\mathrm{H} 2 \quad: \\
\text { "Organization } \\
\text { capabilities has } \\
\text { positive impact to } \\
\text { business } \\
\text { performance" }\end{array}$ & $\begin{array}{l}\text { CR : } 3,301 \\
P<0,05 \\
\text { Output } \\
\text { estimation: } \\
0,247\end{array}$ & $\begin{array}{l}\text { Organization capabilities has positive } \\
\text { impact to business performance. The } \\
\text { impact of this is } 24,7 \% \text {, so there is } \\
75,3 \% \text { consist of other factors which has } \\
\text { impact to business performance. }\end{array}$ & Accepted \\
\hline
\end{tabular}

Discussion H2: Ghazali, Nasyira et al. (2014) said that a good organization capability will make a good commitement within organization, after that it will increase the work motivation of the worker. This statement is in line with the result that organization capability which consist of a high work motivation has positive impact to business performance.

\begin{tabular}{|c|c|c|c|c|}
\hline 3 & $\begin{array}{l}\text { H3 : } \\
\text { "Entreprenuership } \\
\text { has positive impact to } \\
\text { business } \\
\text { performance" }\end{array}$ & $\begin{array}{l}\text { CR : }-3,920 \\
P<0,05 \\
\text { Output } \\
\text { estimation: } \\
0,312 \text {. }\end{array}$ & $\begin{array}{l}\text { Entreprenuership has negative impact } \\
\text { to business performance. The impact of } \\
\text { this is } 31,2 \% \text {, so there is } 68,8 \% \text { consist } \\
\text { of other factors which has impact to } \\
\text { business performance. }\end{array}$ & $\begin{array}{l}\text { Accepted with } \\
\text { significantly } \\
\text { negative } \\
\text { relationship }\end{array}$ \\
\hline \multicolumn{5}{|c|}{$\begin{array}{l}\text { Discussion H3: Altinay dan Altinay (2004) said that innovation is a complex activity and needs many resouces. In } \\
\text { contrary, the owner of SME restaurants only have a limit resource, so they don't have many alternatives to choose. }\end{array}$} \\
\hline 4 & $\begin{array}{l}\mathrm{H} 4 \quad: \\
\text { "Organization } \\
\text { capabilities has } \\
\text { positive impact to } \\
\text { competitive }\end{array}$ & $\begin{array}{l}\text { CR : } 5,065 \\
P<0,05 \\
\text { Output } \\
\text { estimation: } \\
0,398\end{array}$ & $\begin{array}{l}\text { Organization capabilities has positive } \\
\text { impact to competitive advantage in } \\
\text { goodness of taste. The impapct of this is } \\
39,8 \% \text {, so there is } 60,2 \% \text { consist of } \\
\text { other factors which has impact to }\end{array}$ & Accpeted \\
\hline
\end{tabular}




\begin{tabular}{|c|c|c|c|c|}
\hline & $\begin{array}{l}\text { advantage in } \\
\text { goodness of taste" }\end{array}$ & & $\begin{array}{l}\text { competitive advantage in goodness of } \\
\text { taste. }\end{array}$ & \\
\hline \multicolumn{5}{|c|}{$\begin{array}{l}\text { Discussion H4: This result is in line with Liu, Hou et al, (2011) who stated that organization capabilities is the key } \\
\text { to build competitive advantage. Most people think that most owner of SME restaurats have a limit capability wheter } \\
\text { in knowledge or skill, but this limitation could push the owners to become more creative. }\end{array}$} \\
\hline 5 & $\begin{array}{l}\text { H5 : } \\
\text { "Entreprenuership } \\
\text { has positive impact to } \\
\text { competitive } \\
\text { advantage in } \\
\text { goodness of taste" }\end{array}$ & $\begin{array}{l}\text { CR : } 3,377 \\
\text { P }<0,05 \\
\text { Output } \\
\text { estimation: } \\
0,289\end{array}$ & $\begin{array}{l}\text { Entreprenuership has positive impact to } \\
\text { competitive advantage in goodness of } \\
\text { taste. The impapct of this is 28,9\% } \\
\text { consist of other factors which has } \\
\text { impact to competitive advantage in } \\
\text { goodness of taste. }\end{array}$ & Accepted \\
\hline
\end{tabular}

Discussion H5: This result is in line with Bakar dan Ahmad (2010) who stated that innovation could build competitive advantage and become a factor to lead a success. The limitation of resource can make the owners become creative to create a special taste.

Source: Data (2017)

\section{CONCLUSION AND SUGGESTION}

In brief, this research showed that there is a significantly negative relationship between entreprenuership and business performance. It impact to relationship between entreprenuership and business performance that be moderated by competitive advantage. This relationship is significantly negative too. It makes the owners should focus to maintan the taste and don't take a high risk to create a new taste. Take a high risk to create a noew taste will impact to decrease business performance. So, what the owners can do to increase the business performance is increasing the organization capabilities. It will directly impact to the increasing of business performance.

In another hand, some suggestions that the owners can do to directly increase business performance are (1) The owners should make more dicipline for all employees, (2) The owners should have a good relationship to suppliers, (3) The owners should not take a high risk decision to crease someting new to gather new opportunities, (4) The owners should increase the sprit of all employees, and (5) The owners should have a good relationship to buyers (like point 2 stated before). Business performance could indirectly increased by focus in maintain and improve the taste. The taste is the main attraction for buyers and could impact the buyers decision. If the owners focus to find something new (innovation) to attract buyers, the limit resources will used uneffectively. It is becaused the innovation will face a trial and error before can be accepted successfully by buyers.

\section{REFERENCES}

Airlangga, B., L. Suharni, et al. (2015). Klasifikasi Baku Lapangan Usaha Indonesia (KBLI). Jakarta.

Almeida, M. d. M. A., K. Bremser, et al. (2014). "Proactive and Reactive Strategies Deployed by Restaurants in Times of Crisis: Effects on Capabilities, Organization and Competitive Advantage." International Journal of Contemporary Hospitality Management 27: 22.

Altinay, L. and M. Altinay (2004). "The Influence of Organisational Structure on Entrepreneurial Orientation and Expansion Performance." International Journal of Contemporary Hospitality Management 16: 11. 
Arik, M. and T. C. Dunne (2014). "Resource - Based Perspective of Education: A Multi-level Analysis of The Value of Creating Human Capital." The Journal of Applied Management and Entrepreneurship 19: 22.

Arshad, A. S., A. Rasli, et al. (2013). "The Impact of Entrepreneurial Orientation on Business Performance: A Study of Technology-based SMEs in Malaysia." Procedia - Social and Behavioral Sciences 130: 8.

Awang, A., S. A. Khalid, et al. (2009). "Entrepreneurial Orientation and Performance Relations of Malaysian Bumiputera SMEs: The Impact of Some Perceived Environmental Factors." International Journal of Business and Management 4: 13.

Bakar, L. J. A. and H. Ahmad (2010). "Assessing The Relationship Between Firm Resources and Product Innovation Performance : A Resource - Based View." Business Process Management 16: 17.

BPS. (2014 - 2005). “Kecamatan Kota Semarang Dalam Angka 2014 - 2005”. Semarang: Bappeda Kota Semarang dan BPS Kota Semarang.

Ghazali, H., M. N. Nasyira, et al. (2014). "Predictors of intention to stay for employees of casual dining restaurant in Klang Valley area." International Food Research Journal 21: 10.

Joung, H.-W., B. K. Goh, et al. (2015). "Investigating Relationships Between Internal Marketing Practices and Employee Organizational Commitment in The Foodservice Industry." International Journal of Contemporary Hospitality Management 27: 24.

Kurniawati, D. and H. Yuliando (2014). Productivity Improvement of Small Scale Medium Enterprises (SMEs) on Food Products: Case at Yogyakarta Province, Indonesia. The 2014 International Conference on Agro-industry (ICoA): Competitive and sustainable Agroindustry for Human Welfare, Elsevier B.V.: 6.

Lee, C., R. Hallak, et al. (2015). "Innovation, Entrepreneurship, and Restaurant Performance : A Higher-Order Structural Model." Tourism Management 53: 14.

Lee, T. and W. Chu (2011). "Entrepreneurial Orientation and Competitive Advantage: The Mediation of Resource Value and Rareness." African Journal of Business Management 5: 14 .

Limakrisna, N., A. Sudarso, et al. (2015). Entrepreneurship Orientation for Building Business Performance: An Empirical Study Distro Small Medium Enterprises Bandung City. 2nd AFAP International Cenference on Entreprenuerial and Business Management (AICEBM 2015). Universiti Teknologi Malaysia, Kuala Lumpur, Malaysia. 5: 6.

Liu, H., J. Hou, et al. (2011). "Entrepreneurial Orientation, Organizational Capability, and Competitive Advantage in Emerging Economies: Evidence From China." African Journal of Business Management 5: 12.

Mahdi, O. R., M. K. Almsafir, et al. (2011). "The Role of Knowledge and Knowledge Management in Sustaining Competitive Advantage Within Organizations : A Review." African Journal of Business Management 5: 21.

Min, H. and H. Min (2011). "Benchmarking the Service Quality of Fast - Food Restaurant Franchises in The USA : A longitudinal study." Lournal of Accounting, Finance \& Management Strategy 18: 20.

Monsur, S. M. T. and T. Yoshi (2011). "Improvement of Firm Performance by Achieving Competitive Advanteges Through Vertical Integration in The Apparel Industry of Bangladesh." Asian Economic and Financial Review 2: 27.

Munjal, S. and S. Sharma (2012). "Applying Innovative Food Cost Management Practices in Inflationary Times : Indian Budget Restaurant Segment Experiences." Worldwide Hospitality and Tourism Themes 4: 16. 
Ndubisi, N. O. and K. Iftikhar (2012). "Relationship Between Entrepreneurship, Innovation and Performance : Comparing Small and Medium-Size Enterprises." Journal of Research in Marketing and Entrepreneurship 14: 24.

Pérez-de-Lema, D. G., E. Alfaro-Cortes, et al. (2012). "Strategy, Competitive Factors and Performance in Small and Medium Enterprise (SMEs)." African Journal of Business Management 6: 14.

Price, D. and M. Stoica (2015). "The Relationship Between Resources and Firm Performance : Factors That Influence SMEs." Academy of Entrepreneurship Journal 21: 12.

Ryu, K., H.-R. Lee, et al. (2010). "The Influence of The Quality of The Physical Environment, Food, and Service on Restaurant Image, Customer Perceived Value, Customer Satisfaction, and Behavioral Intentions." International Journal of Contemporary Hospitality Management 24: 25.

Setyawati, H. A. (2012). "Pengaruh Orientasi Kewirausahaan dan Orientasi Pasar Terhadap Kinerja Perusahaan Melalui Keunggulan Bersaing dan Persepsi Ketidakpastian Lingkungan Sebagai Prediksi Variabel Moderasi (Survey pada UMKM Perdagangan di Kabupaten Kebumen)."

Tibon, M. V. P. (2015). "The Influence of Organizational Capabilities on Environmental Strategies in The Restaurant Sector : SME Experience." International Journal of Entrepreneurship 19: 14.

Todericiu, R., A. Serban, et al. (2013). Particularities of Knowledge Worker's Motivation Strategies in Romanian Organizations. International Economic Conference of Sibiu 2013 Post Crisis Economy: Challenges and Opportunities, Elsevier: 9.

Tomescu, A. M. and E. A. Botezat (2014). Culinary Tourism in Romania - Professional Points of View. Congress Proceedings : Trends in Tourism and Hospitality Industry.

Tüzünkan, D. and A. Albayrak (2015). Research About Moleculer Cuisine Application As An Innovation Example In Istanbul Restaurants. World Conference on Technology, Innovation and Entrepreneurship, Elsevier Ltd: 7.

Zhang, Y. and X. e. Zhang (2012). "The Effect of Entrepreneurial Orientation on Business Performance : A Role of Network Capabilities in China." Journal of Chinese Entrepreneurship 4: 12. 